\title{
Aging, mental health, and suicide. An integrative review
}

João Manoel Borges de Oliveira ${ }^{1}$ Ivânia Vera²

Roselma Lucchese $^{2}$ Graciele Cristina Silva²

Eryelg Moura Tomé ${ }^{3}$ Roberta Almeida Elias 3

\section{Abstract}

Objective: this integrative literature review aimed to systematize scientific production regarding the process of aging, mental health, and suicide. Method: the LILACS, MEDLINE, and PubMed databases were used to search for papers published between 2007 and 2017. The final analysis included 34 papers. Result: descriptive North American studies in English were most prevalent. The largest number of papers on the theme was published in 2013. The researchers used questionnaires and interviews as instruments for questions involving aging and suicidal ideation. The papers revealed an association of suicide or suicidal ideation in elderly persons who manifested anxiety, depressive symptoms, depression, physical diseases, low educational and socioeconomic levels, and chronic diseases. Conclusion: this integrative review reinforces the need for investment in public policies and spaces that offer receptiveness, listening, and safety for the aged population, as well as surveys with more robust methodologies to investigate the phenomenon under analysis.

\footnotetext{
Centro de Ensino Superior de Catalão, Programa de graduação em Psicologia. Catalão, Goiás, Brasil.

2 Universidade Federal de Goiás, Regional Catalão, Instituto de Biotecnologia, Programa de Pós-Graduação em Gestão Organizacional. Curso de Enfermagem. Catalão, Goiás, Brasil.

3 Universidade Federal de Goiás, Regional Catalão, Programa de Pós-Graduação em Gestão Organizacional. Catalão, Goiás, Brasil.
}

Keywords: Aging. Suicide. Mental Health. Public Health. 


\section{INTRODUCTION}

In the twenty-first century population aging is resulting in almost 58 million new sexagenarians every year, making it clear that the phenomenon cannot be ignored. Furthermore, for every 84 male sexagenarians, there are 100 women of the same age, confirming the feminization of old age. This situation brings many challenges: social, economic and cultural, both individually and collectively (society), and above all within the family ${ }^{1}$.

From the individual perspective, which reflects on the collective and familiar scenario, one can cite the changes brought about by aging itself, inherent phenomena and important fields of investigation and research. These modifications are not limited to biological aspects as a consequence of lifelong wear and tear, but also include psychosocial factors involving personality, life history, gender and socioeconomic context ${ }^{2,3}$.

Physiologically, aging has a direct relationship with the incidence of chronic noncommunicable diseases (CNCD), such as cardiovascular and respiratory diseases, neoplasia and diabetes mellitus, resulting in functional disability and considerable changes in the habits and quality of life of the individual ${ }^{3}$.

Researchers ${ }^{4}$ have identified an association between chronic pathologies and their negative impact on the quality of life of the elderly. Depression is a risk factor for a poor prognosis of chronic diseases, affecting the individual's functional capacity and quality of life ${ }^{4}$. The presence of a physical illness may contribute to the worsening of depression, through its effect on direct brain function, or psychological and psychosocial effects. Thus, just as depression anticipates chronic diseases, so these pathologies accentuate depressive symptoms ${ }^{4}$.

In relation to the contemporary events of old age, it has been seen that the more advanced the age, the greater the mortality rate in relation to attempts of suicide ${ }^{5}$. In its criteria for depressive states the Diagnostic and Statistical Manual of Mental Disorders - Fifth Edition (DSM-V) includes factors such as recurrent thoughts of death (not just fear of dying), recurrent suicidal ideation without a specific plan, or a suicide attempt or specific plan to commit suicide $^{6}$. Suicidal ideation is understood as all the expressions, desires, thoughts and behaviors aimed at ending one's own life without the effectuation of the act. Self-extermination practices that do not achieve their goal are called suicide attempts ${ }^{7}$

Faced with such challenges and manifestations of aging, it is necessary to assess the means of research and investigation into the subject in order to allow a better analysis and understanding of those who face such events. The research question posed was: which aspects influence suicidal ideation in the elderly? In this way we tried to systematize the knowledge produced about the suicidal ideation of elderly persons.

\section{METHOD}

An integrative literature review was used as a research method. This methodology allows the synthesizing of the state of the art of knowledge about the subject of interest, following the steps: identification of the theme, selection of the hypothesis or research question; establishing of criteria for inclusion and exclusion of studies/ sampling; definition of the information to be extracted from the selected studies; evaluation of included studies; interpretation of results; and presentation of knowledge review/synthesis ${ }^{8}$.

In order to carry out this integrative review, the following databases were selected: Latin American and Caribbean Health Sciences Literature (LILACS), MEDical Literature Analysis and Retrieval System (MEDLINE) and PubMed. The research was carried out between October and November 2017, and the collection was carried out simultaneously by two researchers. The following controlled descriptors in health were used: "Aging" and "Mental Heath" and "Suicide".

We included only original, complete articles with an exclusively epidemiological methodology, which were available free online, published between the years 2007 and 2017, and in English, Portuguese and Spanish. In order to increase the reliability of the information from the databases, a manual search of available articles (search by hand) was carried out, based on the references of the articles already collected. 
To analyze the data, the articles were translated and read, followed by the systematization and transcription of the extracted information, allowing the publications that met the inclusion criteria to be organized. The following information of interest was extracted: authors, article title, year of publication, country of origin, database, sample, study design, level of evidence, instruments and indexes used by researchers in the original study, results and synthesis of conclusions.

With the aim of analyzing the level of evidence, the following hierarchical classification was used: level I - evidence of results of meta-analysis from controlled clinical trials with randomization; level II - evidence of experimental design studies; level III - evidence of quasi-experimental studies; level IV for evidence obtained from non-experimental, descriptive or qualitative methodological approaches; level $\mathrm{V}$ for evidence of case or experience reports; and level VI for evidence based on expert opinions or standards or legislation?

\section{RESULTS}

The sample of this integrative review resulted in one article in the LILACS database (5.2\%), one in PubMed (5.2\%) and 17 in MEDLINE (89.4\%) being found. From these texts, through a search by hand, five articles indexed in LILACS and ten in MEDLINE were also included. As four productions were repeated across the platforms, the search resulted in a total of 34 articles for final analysis, 27 from MEDLINE (79.4\%), six from LILACS (17.6\%) and one from PubMed (2.9\%).

Figure 1 shows the steps of this integrative review.

In terms of the origin of the studies, $76.4 \%$ were from North America, 17.6\% from Latin America and $5.8 \%$ from Europe. The English language was most prevalent (85.2\%), followed by Portuguese (8.8\%) and Spanish (5.8\%). There was a considerable number of studies with a descriptive approach (88.2\%), followed by those with a qualitative approach $(11.7 \%)$, characterized as level IV in the hierarchical classification?

The analysis of selected articles showed that the 2013 was the year with the greatest number of publications (20.5\%), followed by 2014 (17.6\%); 2015 and 2010 (14.7\%); 2007, 2009, 2011, 2012 and 2016 (5.8\% each); and 2008 (2.9\%). No article was found that met the criteria for inclusion in 2017. Table 1 presents a brief description of the articles selected for this integrative review, together with the synthesis of the results of the selected texts.

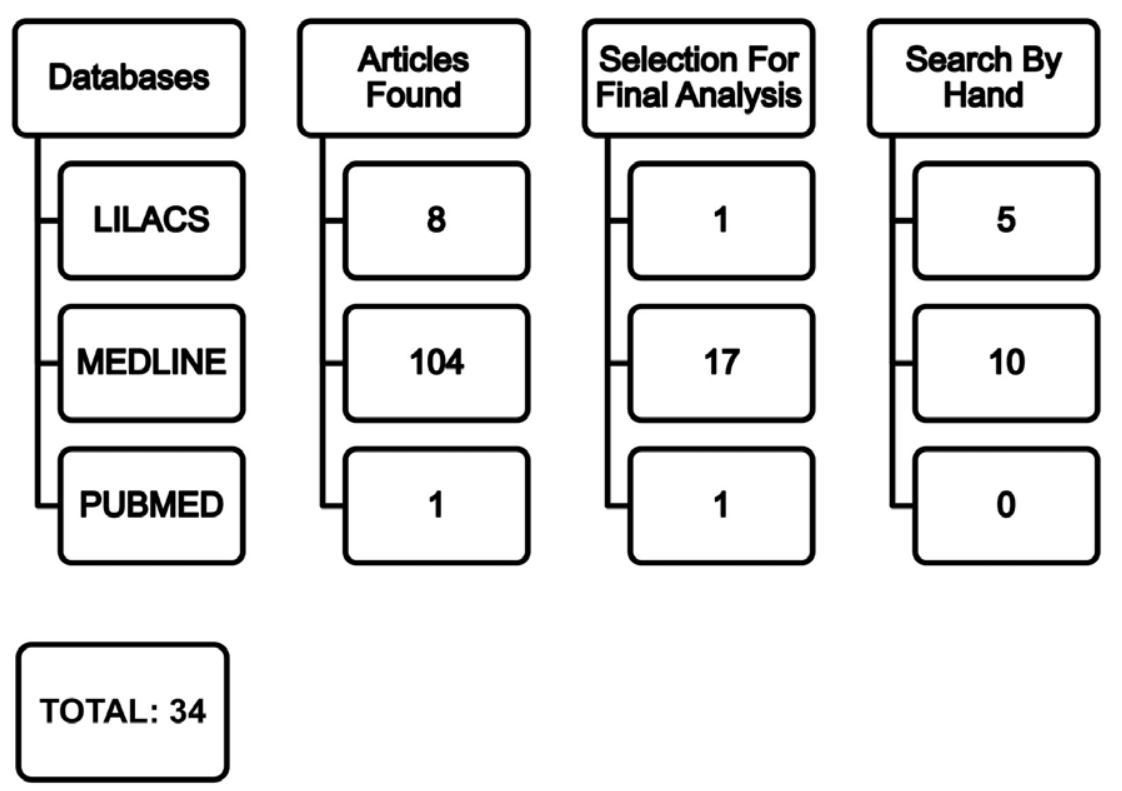

Figure 1. Flowchart of selection process of articles in sample, 2007-2017. Catalão, Goias, 2017. 


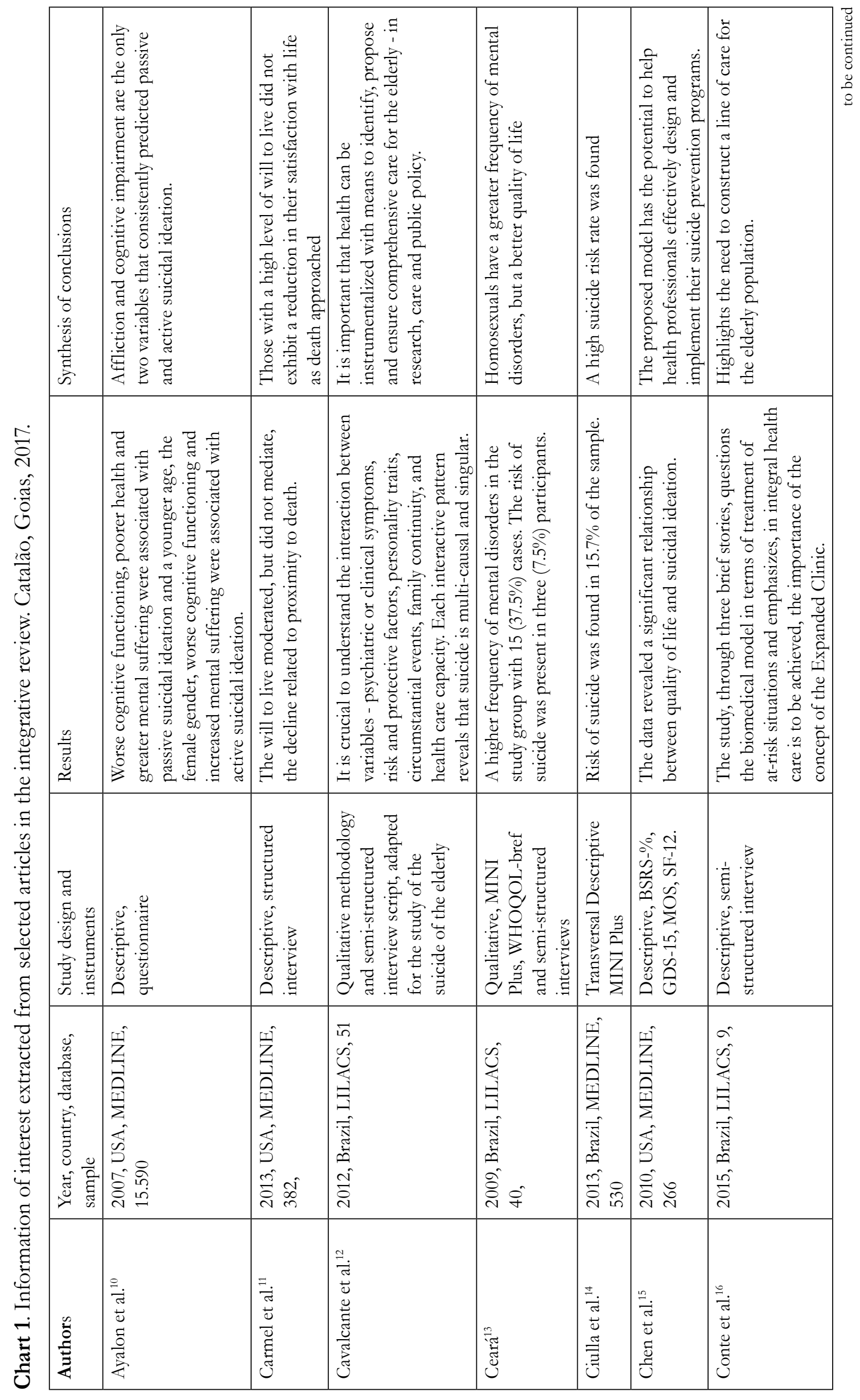




\begin{tabular}{|c|c|c|c|c|c|c|c|c|}
\hline 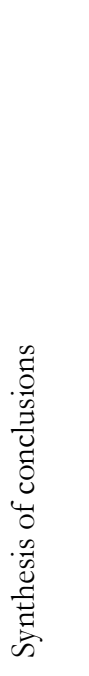 & 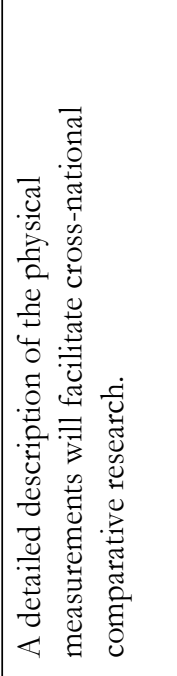 & 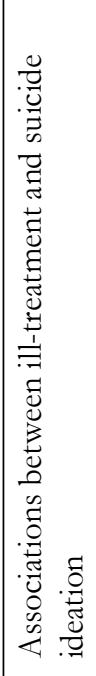 & 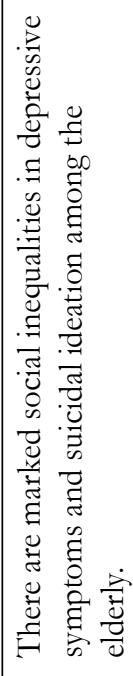 & 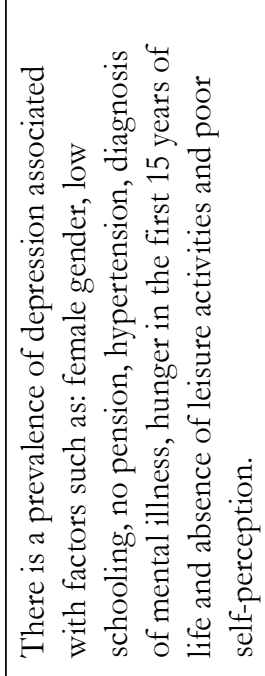 & 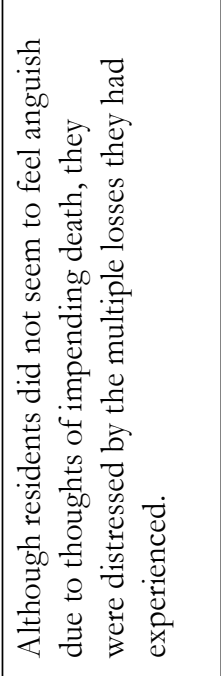 & 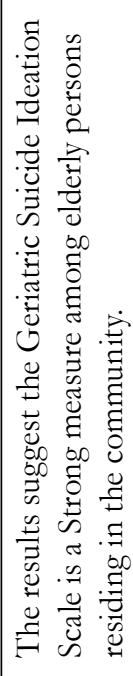 & 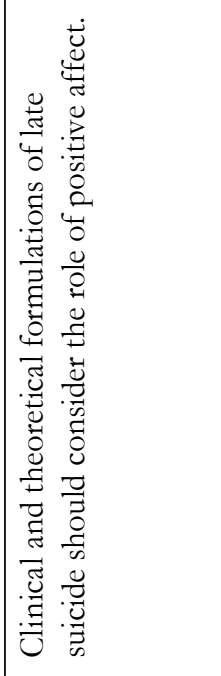 & 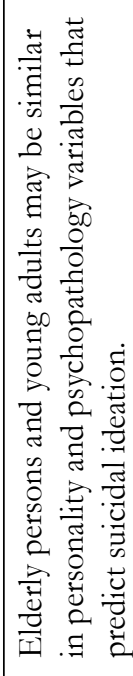 \\
\hline 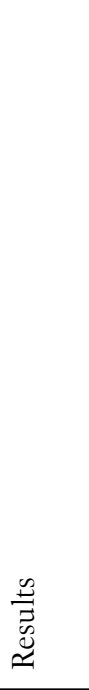 & 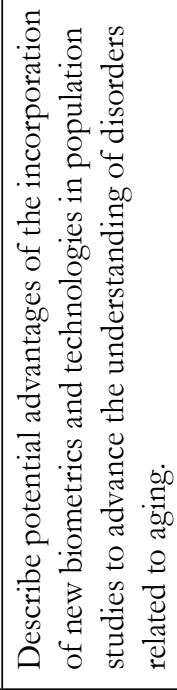 & 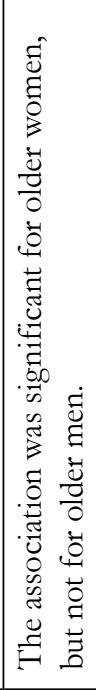 & 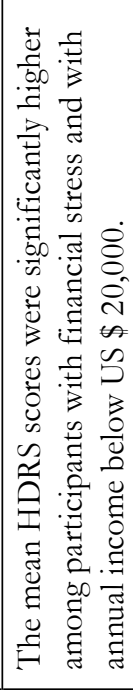 & 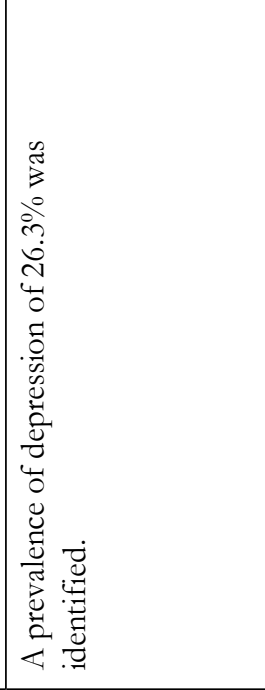 & 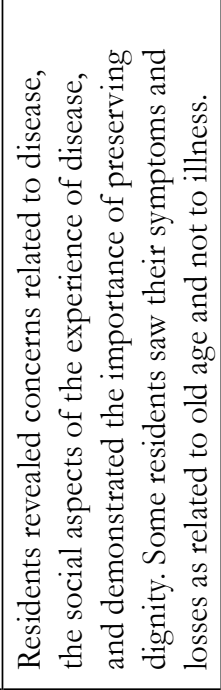 & 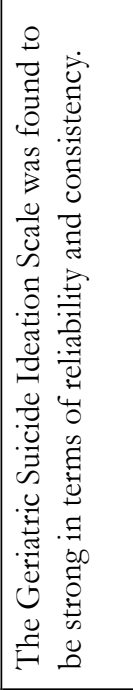 & 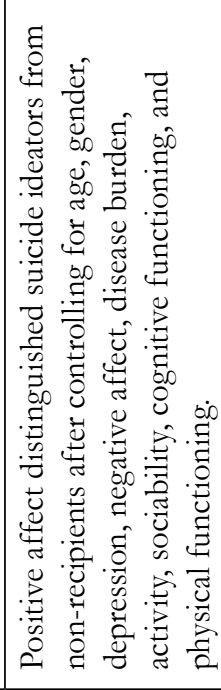 & 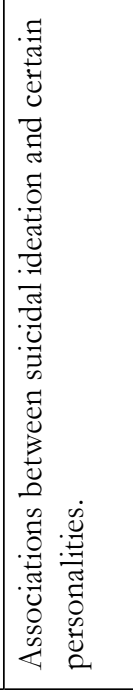 \\
\hline 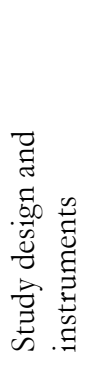 & 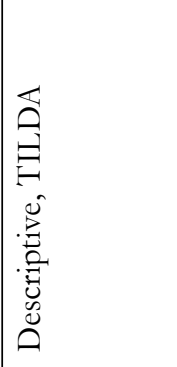 & 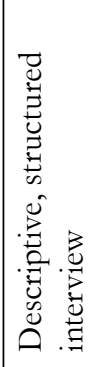 & 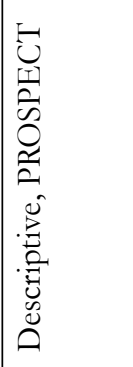 & 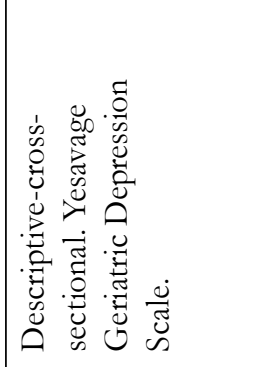 & 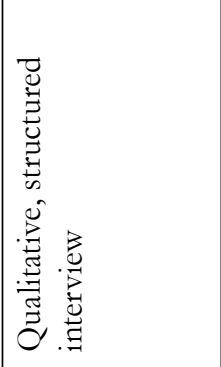 & 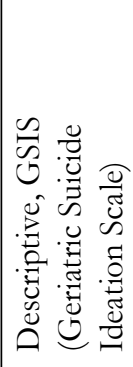 & 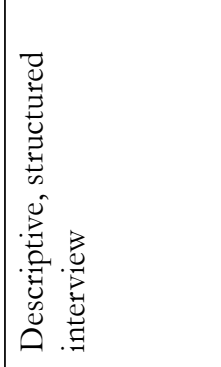 & 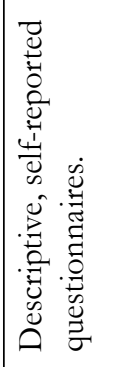 \\
\hline 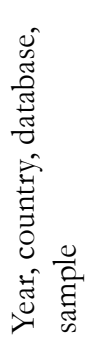 & 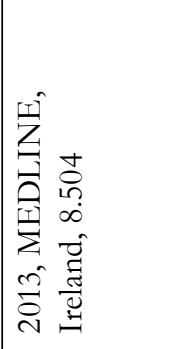 & 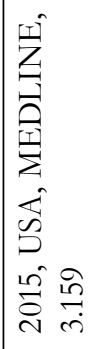 & 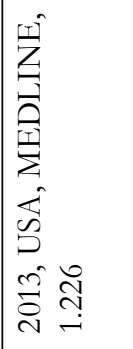 & 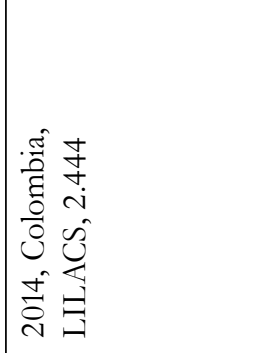 & 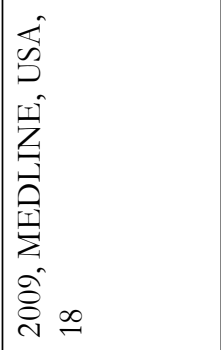 & 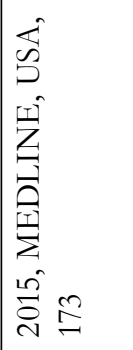 & 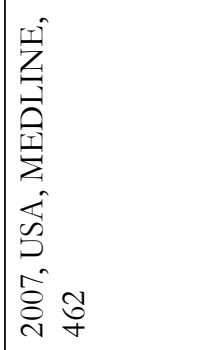 & 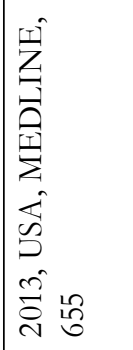 \\
\hline 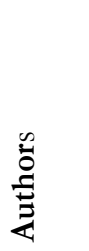 & 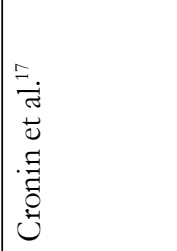 & 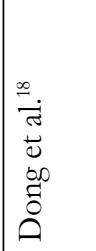 & 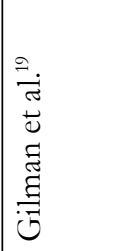 & 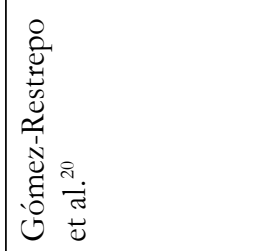 & 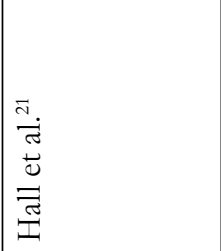 & 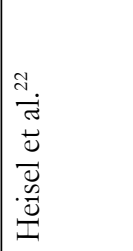 & 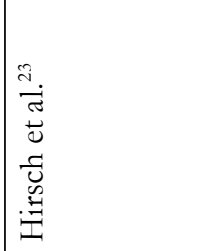 & 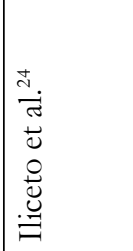 \\
\hline
\end{tabular}




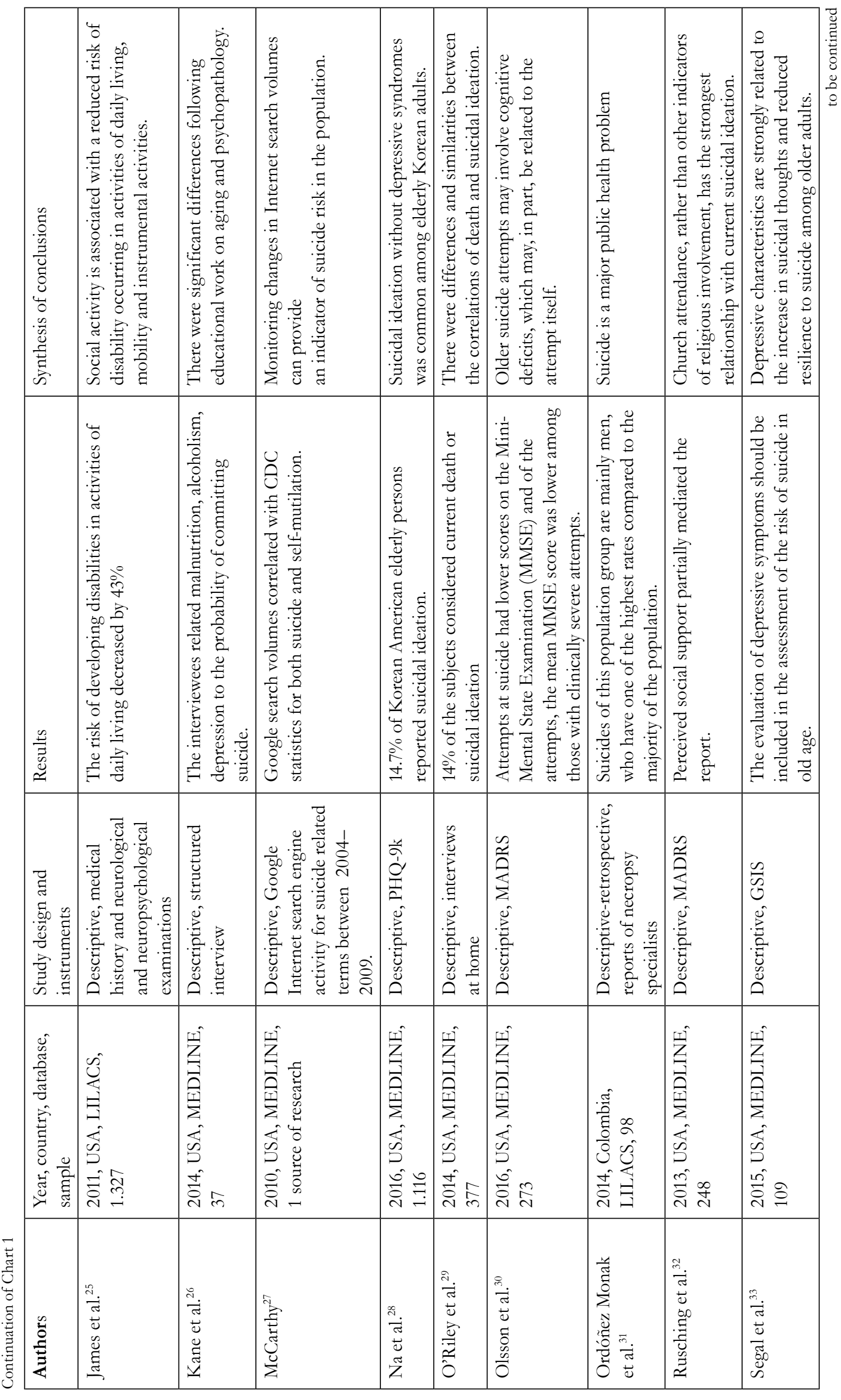




\begin{tabular}{|c|c|c|c|c|c|c|c|c|c|c|c|}
\hline 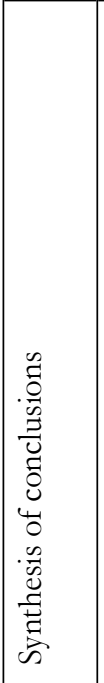 & 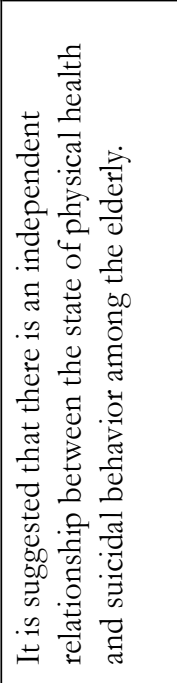 & 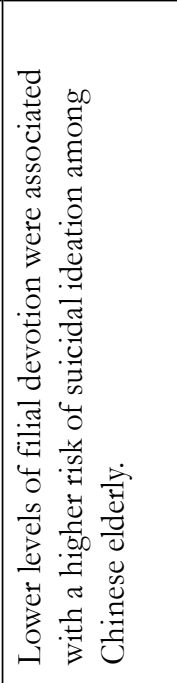 & 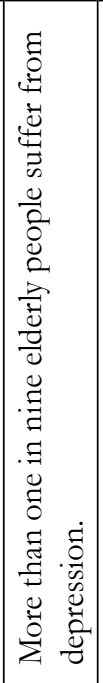 & 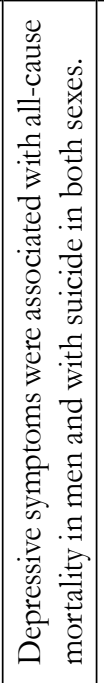 & 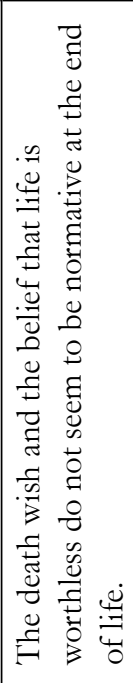 & 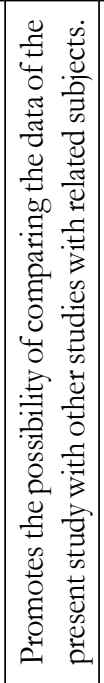 & 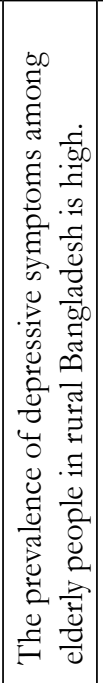 & 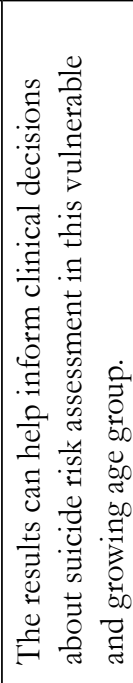 & 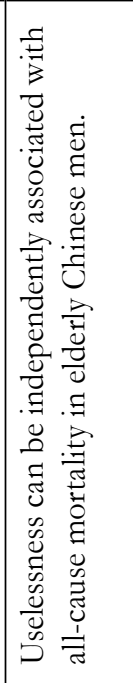 & 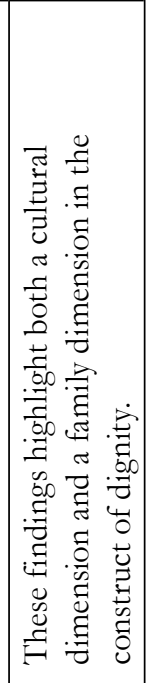 & 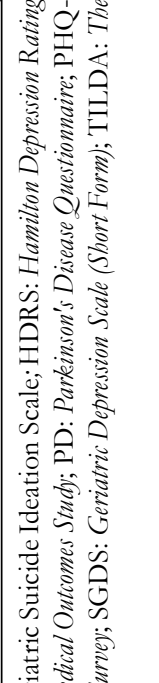 \\
\hline$\frac{n}{5}$ & 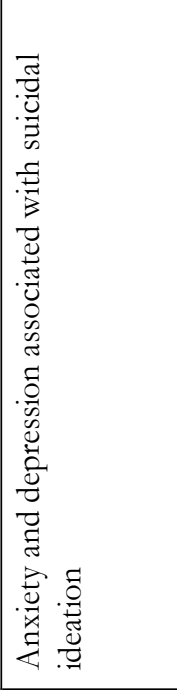 & 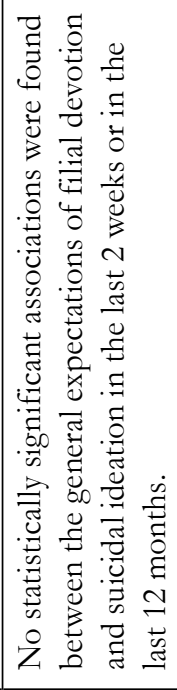 & 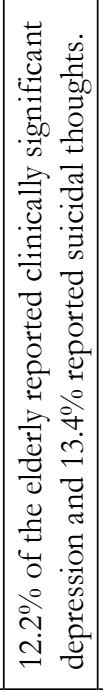 & 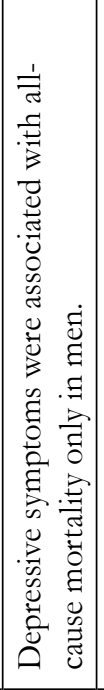 & 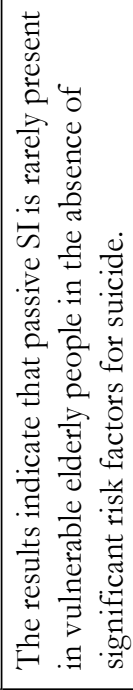 & 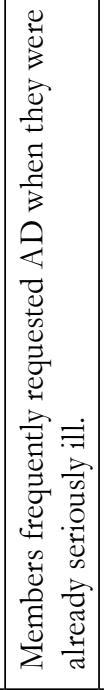 & 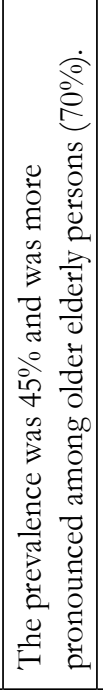 & 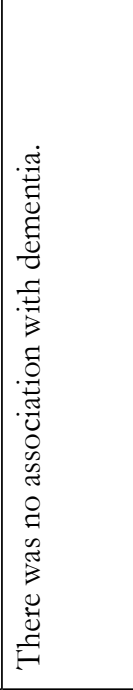 & 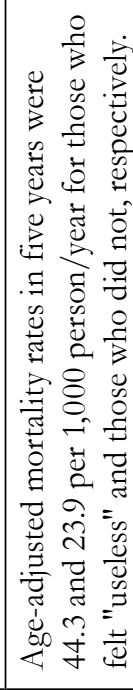 & 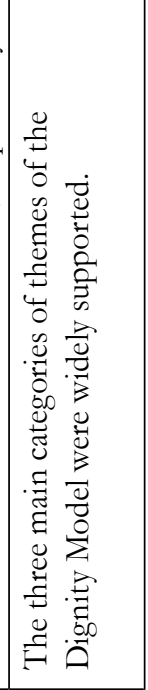 & s) \\
\hline 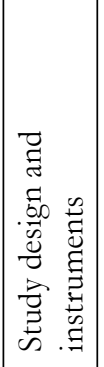 & 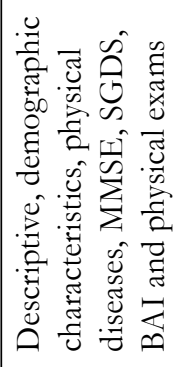 & 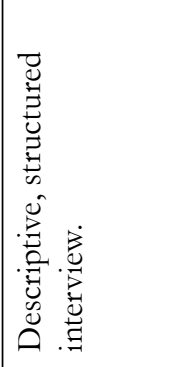 & 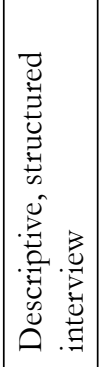 & 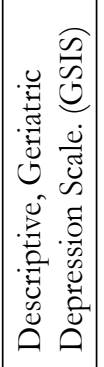 & 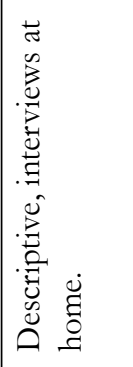 & 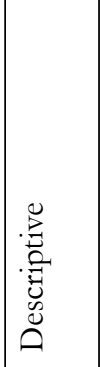 & 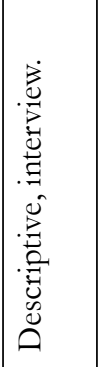 & 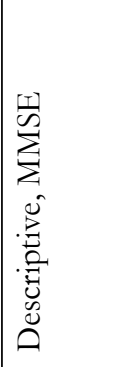 & 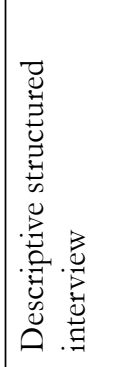 & 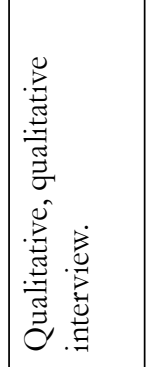 & 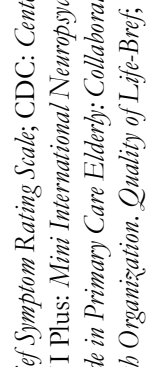 \\
\hline 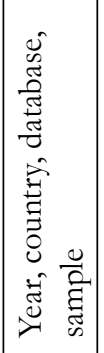 & 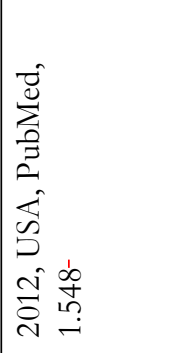 & 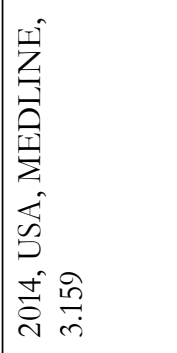 & 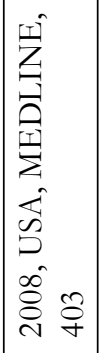 & 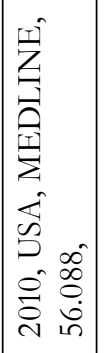 & 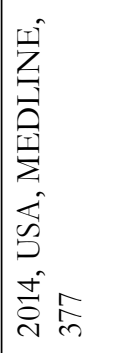 & 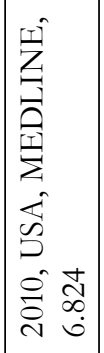 & 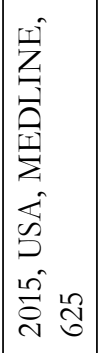 & 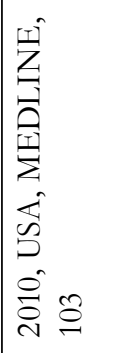 & 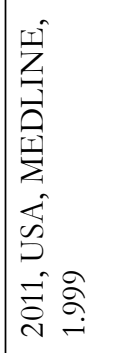 & 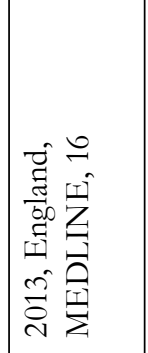 & \\
\hline 产 & 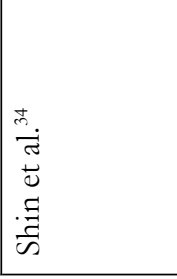 & $\begin{array}{l}\text { ] } \\
\tilde{J} \\
\tilde{\Delta} \\
\tilde{0}\end{array}$ & \begin{tabular}{|l}
0 \\
$\tilde{\sigma}$ \\
0 \\
0
\end{tabular} & $\mid \begin{array}{c}\overrightarrow{0} \\
\tilde{0} \\
0 \\
\Xi \\
0\end{array}$ & 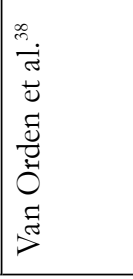 & 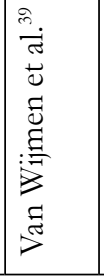 & 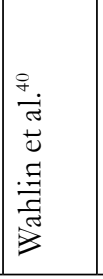 & 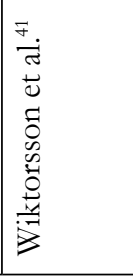 & $\begin{array}{l}\pi \\
\tilde{J} \\
0 \\
0 \\
0 \\
0 \\
0\end{array}$ & 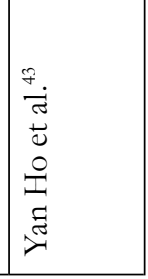 & \\
\hline
\end{tabular}




\section{DISCUSSION}

The majority of the articles found were from the MEDLINE database. The largest number of publications were published in 2013, followed by 2014, a fact that may be explained by the publication of the Good Health Adds Life To Years: Global Brief for World Health report by the World Health Organization (WHO) in 2012, which encouraged discussions on the phenomenon of aging and its impact on various sectors of society. The report presented data on the state of old age in the world, the demography and epidemiology of population aging, and possible actions on aging and health ${ }^{44}$.

The investigation pointed out that 28 articles $(82.3 \%)$ used the application of questionnaires and interviews, with the aim of investigating the aspects involved in aging and suicidal ideation. Instruments such as scales are useful for the detection of depressive symptoms self-reported by the elderly ${ }^{45}$. In addition, actions that require on-site examination of the relationships, interactions and lifestyles of the elderly are fundamental for establishing a relationship between aging and possible suicidal behavior. It is important to harmonize clinical and social evidence, as well as epidemiological data, with reports of the elderly themselves about their life trajectory and their reasons for giving up on living ${ }^{46}$.

An association between suicide or suicidal ideation in the elderly and factors such as anxiety ${ }^{34}$, depressive symptoms and depression ${ }^{14,20,23,26,36,37}$, physical and chronic diseases ${ }^{16,25,31,34}$, low schooling ${ }^{20}$, low socioeconomic status ${ }^{19}$ and ill-treatment ${ }^{25}$ was found. The studies indicate a relationship between physical health status, the absence of leisure activities and less social support and a greater possibility of suicide attempts ${ }^{16,18,34}$. Thus, higher levels of social and physical activity confer benefits to the health of the elderly, reducing daily disability and depressive symptoms that can lead to suicide ${ }^{25}$.

It is known that elderly people with depression may have considerable cognitive and functional disorders, and that the changes due to aging may lead to certain alterations. It is observed that both cognitive impairment and mental suffering among the elderly increase the probability of suicidal ideation ${ }^{10}$. The most recurrent cognitive variations in depressed elderly persons are executive functions, attention deficit, and the slowing of processing ${ }^{47}$.

As a multifactorial process, aging causes anatomical and functional changes in the body. Such alterations may result in the appearance of chronic and degenerative diseases ${ }^{16,25,31,34}$, such as pulmonary diseases, arterial hypertension, osteoporosis, arthritis, dementias or mental disorders, heart diseases, arthrosis, rheumatism, stroke and cancer, reducing the functional capacity and quality of life of the elderly person ${ }^{48}$. All these factors increase the chances of suicidal ideation and suicide itself in the elderly ${ }^{31}$.

Another finding observed in the analysis of the articles was the need to invest in reception, therapies, discussion circles, groups, forums and health conferences as health care strategies ${ }^{16}$. The absence of a space for listening and reception in the health and social services, as well as the lack of a health professional who can support elderly individuals, can increase their vulnerability to the risk of suicide ${ }^{16}$, with such measures an effective protection against suicide.

There is a need for strategies that favor the prevention of mental disorders, the treatment of diseases with the inclusion of diagnostic procedures, early detection, correct medication, psychotherapy and the training of professionals and other persons involved with this population group $^{49}$. The understanding of care in the quality of life as encompassing physical, psychological and social aspects allows the involvement of health professionals in the construction and effective implementation of suicide prevention programs in addition to potentializing opportunities of detection of the mental health needs of the elderly ${ }^{15,36}$.

Limitations of the present study include the methodology used, considering its level of scientific evidence compared to other methodologies such as systematic reviews or a meta-analysis. However, through the hierarchical level of methodological classification, the present study identified a predominance of level IV studies, which suggests that new studies on suicide among the elderly employ 
more robust methodologies and designs that produce consistent evidence.

\section{CONCLUSION}

The aspects related to suicidal ideation in the elderly were a low socioeconomic level, the presence of anxiety, depressive symptoms and depression, physical illnesses and chronic diseases. A multidimensional look at the phenomenon of suicide in the elderly is required, based on economic, psychological, physical and social factors, both by professionals who work in the field of aging and by the state, with public policies that support this population. Although the growth of the elderly population is an indisputable reality, the support given to such individuals has not advanced with the same speed. In this way, living spaces that offer physical and leisure activities, access to health care of all levels of complexity, social and

\section{REFERENCES}

1. Fundo de População das Nações

Unidas. Envelhecimento no século XXI: celebração e desafio: resumo executivo. Nova York: UNFPA; 2012.

2. Curado EM, Campos AP, Decnop VL. Como é estar na velhice?: a experiência de mulheres idosas participantes de uma intervenção psicológica grupal. SER Soc. 2007:21:45-69.

3. Freitas EV. Avaliação geriátrica ampla. In: Freitas EV, Mohallem KL, Gamarski R, Pereira SRMl. Manual prático de geriatria. Rio de Janeiro: AC Farmacêutica; 2014. p.1-12.

4. Silva JV, Silva EC, Rodrigues AP, Miyazawa AP. A relação entre o envelhecimento populacional e as doenças crônicas não transmissíveis: sério desafio de saúde pública. Cad Grad Ciênc Biol Saúde. 2015;2(3):91-100.

5. Silva AR, Sgnaolin V, Nogueira EL, Loureiro F, Engroff P, Gomes I. Doenças crônicas não transmissíveis e fatores sociodemográficos associados a sintomas de depressão em idosos. J Bras Psiquiatr. 2017;66(1):45-51.

6. Pedrosa B, Duque R, Martins R. Suicídio no Idoso: o antecipar da morte. PsiLogos. 2016;14(1):50-6.

7. American Psychiatric Association. DSM-5: Manual diagnóstico e estatístico de transtornos mentais. Porto Alegre: Artmed; 2014. family support avoiding isolation and solitude, can be considered actions that minimize or avoid suicidal ideation.

The reading of the original texts made it possible to understand the way aging, suicide and mental health issues have been treated in the scientific milieu. Nevertheless, the works studied addressed a relevant and complex topic of study, representing a significant source of knowledge for future research. The results of this review are relevant because, besides evidencing the associations between several factors found in literature and suicide, they also point out ways to promote physical and mental health among the elderly, thus reducing the risk of suicide among this population.

At the same time, the need for greater investment in the area of health is emphasized, strengthening existing public policies through intersectoral collaboration in the health care of the elderly.

8. Figueiredo AE, Silva RM, Vieira LJ, Mangas RM, Sousa GS, Freitas JS, et al. É possível superar ideações e tentativas de suicídio?: Um estudo sobre idosos. Ciênc Saúde Colet. 2015;20(6):1711-9.

9. Mendes KDS, Silveira RC, Galvão CM. Revisão integrativa: método de pesquisa para a incorporação de evidências na saúde e na enfermagem. Texto \& Contexto Enferm. 2008;17(4):758-64.

10. Stetler CB, Morsi D, Rucki S, Broughton S, Corrigan $B$, Fitzgerald J, et al. Utilization- focused integrative reviews in a nursing service. Appl Nurs Res. 1998;11(4):195-206.

11. Ayalon L, Mackin S, Arean PA, Chen H, McDonel Herr EC. The role of cognitive functioning and distress in suicidal ideation in older adults. J Am Geriatr Soc. 2007;55(7):1090-4.

12. Carmel S, Shrira A, Shmotkin D. The will to live and death-related decline in life satisfaction. Psychol Aging. 2013;28(4):1115-23.

13. Cavalcante FG, Minayo MC, Meneghel SN, Silva RM, Gutierrez DM, Conte M, et al. Autópsia psicológica e psicossocial sobre suicídio de idosos: abordagem metodológica. Ciênc Saúde Colet. 2012;17(8):2039-52.

14. Ceará AT, Dalgalarrondo P. Transtornos mentais, qualidade de vida e identidade em homossexuais na maturidade e velhice. Rev Psiquiatr Clin. 2017;37(3):118-23. 
15. Ciulla L, Lopes Nogueira E, da Silva Filho IG, Tres GL, Engroff P, Ciulla V, et al. Suicide risk in the elderly: data from Brazilian public health care program. J Affect Disord. 2014;152-154:513-6.

16. Chen WJ, Chen CC, Ho CK, Chou FH, Lee MB, Lung F, et al. The relationships between quality of life, psychiatric illness, and suicidal ideation in geriatric veterans living in a veterans' home: a structural equation modeling approach. Am J Geriatr Psychiatr. 2011;19(6):597-601

17. Conte M, Cruz CW, Silva CG, Castilhos NR, Nicolella AD. Encontros ou desencontros: histórias de idosos que tentaram suicídio e a Rede de Atenção Integral em Porto Alegre/RS, Brasil. Ciênc Saúde Colet. 2015;20(6):1741-9.

18. Cronin H, O'Regan C, Finucane C, Kearney P, Kenny RA. Health and aging: development of the Irish Longitudinal Study on Ageing health assessment. J Am Geriatr Soc. 2013;61 Suppl 2:269-78.

19. Dong X, Chen R, Wu B, Zhang NJ, Mui AC, Chi I. Association between elder mistreatment and suicidal ideation among community-dwelling Chinese older adults in the USA. Gerontology. 2015;62(1):71-80

20. Gilman SE, Bruce ML, Ten Have T, Alexopoulos GS, Mulsant BH, Reynolds CF, et al. Social inequalities in depression and suicidal ideation among older primary care patients. Soc Psychiatry Psychiatr Epidemiol. 2013;48(1):59-69

21. Gómez-Restrepo C, Rodríguez MN, Díaz N, Cano C, Tamayo N. Depresión y satisfacción con la vida en personas mayores de 60 años en Bogotá: Encuesta de Salud, Bienestar y Envejecimiento (SABE). Rev Colomb Psiquiatr. 2013;42(Suppl. 1):65-70.

22. Hall S, Longhurst S, Higginson I. Living and dying with dignity: a qualitative study of the views of older people in nursing homes. Age Ageing. 2009;38(4):411-6.

23. Heisel MJ, Flett GL. Investigating the psychometric properties of the Geriatric Suicide Ideation Scale (GSIS) among community-residing older adults. Aging Ment Health. 2016;20(2):208-21.

24. Hirsch JK, Duberstein PR, Chapman B, Lyness JM. Positive affect and suicide ideation in older adult primary care patients. Psychol Aging. 2007;22(2):380-5.

25. Iliceto P, Fino E, Sabatello U, Candilera G. Personality and suicidal ideation in the elderly: factorial invariance and latent means structures across age. Aging Ment Health. 2014;18(6):792-800.

26. James BD, Boyle PA, Buchman AS, Bennett DA. Relation of late-life social activity with incident disability among community-dwelling older adults. J Gerontol Ser A Biol Sci Med Sci. 2011;66(4):467-73.
27. Kane MN, Jacobs RJ, Hawkins WE. Attributions of autonomy and competence of older and younger homeless mentally ill. Soc Work Health Care. 2013;52(1):78-98.

28. McCarthy MJ. Internet monitoring of suicide risk in the population. J Affect Disord. 2010;122(3):277-9.

29. Na PJ, Kim KB, Lee-Tauler SY, Han HR, Kim MT, Lee HB. Predictors of suicidal ideation in Korean American older adults: analysis of the Memory and Aging Study of Koreans (MASK). Int J Geriatr Psychiatr. 2017;32(12):1272-9.

30. O'Riley AA, van Orden KA, He H, Richardson TM, Podgorski C, Conwell Y. Suicide and death ideation in older adults obtaining aging services. Am J Geriatr Psychiatr. 2014;22(6):614-22.

31. Olsson P, Wiktorsson S, Sacuiu S, Marlow T, Östling S, Fässberg MM, et al. Cognitive function in older suicide attempters and a population-based comparison group. J Geriatr Psychiatry Neurol. 2016;29(3):133-41.

32. Ordóñez Monak IA, Agudelo SA, Ortiz JO. Caracterización sociodemográfica de los suicidas adultos mayores de 60 años: Bogotá 2003-2007. Rev Colomb Psiquiatr. 2013;42:56-64.

33. Rushing NC, Corsentino E, Hames JL, SachsEricsson N, Steffens DC. The relationship of religious involvement indicators and social support to current and past suicidality among depressed older adults. Aging Ment Health. 2013;17(3):366-74.

34. Segal DL, Gottschling J, Marty M, Meyer WJ, Coolidge FL. Relationships among depressive, passive-aggressive, sadistic and self-defeating personality disorder features with suicidal ideation and reasons for living among older adults. Aging Ment Health. 2015;19(12):1071-7.

35. Shin KM, Cho SM, Hong CH, Park KS, Shin YM, Lim KY, et al. Suicide among the elderly and associated factors in South Korea. Aging Ment Health. 2013;17(1):109-14

36. Simon MA, Chen R, Chang ES, Dong X. The association between filial piety and suicidal ideation: findings from a community-dwelling Chinese aging population. J Gerontol Ser A Biol Sci Med Sci. 2014;69(Suppl 2):90-7.

37. Sirey JA, Bruce ML, Carpenter M, Booker D, Reid MC, Newell KA, et al. Depressive symptoms and suicidal ideation among older adults receiving home delivered meals. Int J Geriatr Psychiatr. 2008;23(12):1306-11.

38. Sun W, Schooling CM, Chan WM, Ho KS, Lam TH. The association between depressive symptoms and mortality among Chinese elderly: a Hong Kong cohort study. J Gerontol Ser A Biol Sci Med Sci. 2011;66(4):459-66. 
39. van Orden KA, O'Riley AA, Simning

A, Podgorski C, Richardson TM, Conwell Y.

Passive suicide ideation: an indicator of risk among older adults seeking aging services? Gerontologist. 2015;55(6):972-80.

40. Van Wijmen MP, Rurup ML, Pasman HR, Kaspers PJ, Onwuteaka-Philipsen BD. Design of the Advance making focusing on Advance Directives. BMC Public Health. 2010;10:166.

41. Wahlin $\AA$, Palmer K, Sternäng O, Hamadani JD, Kabir ZN. Prevalence of depressive symptoms and suicidal thoughts among elderly persons in rural Bangladesh. Int Psychogeriatr. 2015;27(12):1999-2008.

42. Wiktorsson S, Runeson B, Skoog I, Ostling S, Waern M. Attempted suicide in the elderly: characteristics of suicide attempters 70 years and older and a general population comparison group. Am J Geriatr Psychiatr. 2010;18(1):57-67.

43. Wong SY, Leung JC, Woo J. The relationship between worthlessness and mortality in a large cohort of Chinese elderly men. Int Psychogeriatr. 2011;23(4):609-15.

Received: January 26, 2018

Reviewed: May 08, 2018

Accepted: July 23, 2018

44. Yan Ho AH, Chan CL, Leung PP, Chochinov HM, Neimeyer RA, Pang SM, et al. Living and dying with dignity in Chinese society: perspectives of older palliative care patients in Hong Kong. Age Ageing. 2013;42(4):455-61.

45. World Health Organization. Good health adds life to years: Global brief for World Health Day. Geneva: WHO; 2012.

46. Matias AG, Fonseca MA, Gomes ML, Matos MA. Indicadores de depressão em idosos e os diferentes métodos de rastreamento. Einstein (São Paulo). 2016;14(1):6-11.

47. Cavalcante FG, Minayo MC, Gutierrez DM, Sousa GS, Silva RM, Moura R, et al. Instrumentos, estratégias e método de abordagem qualitativa sobre tentativas e ideações suicidas de pessoas idosas. Ciênc Saúde Colet. 2015;20(6):1667-80.

48. Miranda EC, Pinheiro MM, Pereira LD, Iorio MC. Correlação do potencial evocado P300 com aspectos cognitivos e depressivos do envelhecimento. Braz J Otorhinolaryngol. 2012;78(5):83-9.

49. Santos JG, Pereira JR, Texeira CV, Corazza DI, Vital TM, Costa Jl. Sintomas depressivos e prejuízo funcional de idosos de um Centro-Dia Geriátrico. J Bras Psiquiatr. 2012;61(2):102-6. 